\title{
Efficacy of sodium feredetate versus ferrous sulfate in iron deficiency anemia in preganant women
}

\author{
Vijaya Manohar Revankar ${ }^{1 *}$, Asha Garg1, Manohar G. Revankar²
}

${ }^{1}$ Department of Obstetrics and Gynecology, Kasturba Medical College, Mangalore, Manipal University, Karnataka, India

${ }^{2}$ Pharmacology Department, K. S. Hegde Medical College, Mangalore, Karnataka, India.

Received: 01 March 2017

Accepted: 01 April 2017

\section{*Correspondence:}

Dr. Vijaya Manohar Revankar,

E-mail: vijaya.manohar.revankar@gmail.com

Copyright: ( $)$ the author(s), publisher and licensee Medip Academy. This is an open-access article distributed under the terms of the Creative Commons Attribution Non-Commercial License, which permits unrestricted non-commercial use, distribution, and reproduction in any medium, provided the original work is properly cited.

\begin{abstract}
Background: The main aim of the study was to determine the efficacy of Sodium Feredetate with Ferrous Sulfate in treatment of iron deficiency anemia in pregnant women. Rise in hemoglobin after one and two months of treatment with respective drugs and their side effects.

Methods: Prospective randomized study carried out between Jan 2008-July 2009 at Government Tertiary Care Level Hospital OBG Department in Mangalore on 74 pregnant women with anemia.

Results: Sodium feredetate (Na Fe EDTA) in iron deficiency anemia led to a significant and rapid rise in hemoglobin levels than that with ferrous sulfate in our study.

Conclusions: Sodium Feredetate in iron deficiency anemia led to a significant and rapid rise in hemoglobin levels than that with Ferrous Sulfate and also associated with minimal or no side effects.
\end{abstract}

Keywords: Ferrous sulfate, Iron deficiency anemia, Sodium feredetate

\section{INTRODUCTION}

The main health problem in the world is iron deficiency anemia. The commonest nutritional disorder is iron deficiency anemia mostly affecting the infants, children and women of reproductive age group in the developing countries. WHO reports that $35-75 \%$ of pregnant women in developing countries and $18 \%$ of women from industrialized countries are anemic. ${ }^{1}$

Despite the fact that the daily iron intake of Indians is twice that of westerns, the incidence of iron deficiency anemia is much more in Indians which is attributed to consumption of predominantly cereal based diet, rich in phytates, phosphates, oxalates and other inhibitors of iron absorption. ${ }^{2,3}$ Iron deficiency anemia can be prevented and treated by using iron preparations like ferrous sulphate, fumarate or gluconate. Ferrous salts when given orally cause poor compliance and failure of treatment. To make iron more bioavailable, to reduce the GIT side effects and increasing the patient compliance there are newer formulations like Sodium Iron EDTA (Sodium Feredetate).

It is water soluble and highly bioavailable form of iron. The mean iron absorption of Sodium Feredetate is considered to be approximately 3 times higher than that of ferrous sulfate and is affected slightly by the presence of inhibiting substances in the diet. Hence a study in iron deficiency anemic pregnant women were compared with Sodium Feredetate and Ferrous Sulfate.

\section{METHODS}

The pregnant women selected for the study with iron deficiency anemia were 74 . The study was conducted at 
Government Lady Goschen Hospital Mangalore in the Department of OBG. Institutional ethical committee approval was taken. 74 pregnant women were randomly divided into Sodium Feredetate and Ferrous Sulfate groups. Each group consisted of 37 women. In Ferrous Sulfate group (FS Group), women were dispensed with ferrous sulfate tablets of $200 \mathrm{mg}$ containing $60 \mathrm{mg}$ of elemental iron orally twice a day for two months. In Sodium Feredetate Group (FD group), women were dispensed with sodium feredetate tablets of $231 \mathrm{mg}$ containing $33 \mathrm{mg}$ of elemental iron orally once a day for two months.

\section{Inclusion Criteria}

- Antenatal women having haemoglobin less than $11 \mathrm{~g} / \mathrm{dl}$ but more than $6 \mathrm{~g} / \mathrm{dl}$.

- Gestational age between 12 weeks to 28 weeks.

\section{Exclusion Criteria}

- Patients taking any other iron preparation.

- Twin pregnancy

- Hypertension

- Any bleeding disorders

- Sickle cell anemia, other hemoglobinopathies and other varieties of anemia.

\section{Procedure}

All women were included in the study after taking their consent. Women were screened clinically for anemia, all the necessary investigations for diagnosis of anemia were sent and allocated into one of the two groups randomly. Blood investigations $\mathrm{Hb}, \mathrm{PCV}, \mathrm{MCV}, \mathrm{MCH}, \mathrm{MCHC}$ and peripheral smear were sent. Women with microcytic hypochromic blood anemia with hemoglobin $>6 \mathrm{~g} / \mathrm{dl}$ and $<11 \mathrm{~g} / \mathrm{dl}$ were included in the study. Hb was estimated using SLS-Hb (Sodium Lauryl Sulfate-hemoglobin) method. To both the groups tablets were given for 2 months and follow up was done at 1 month and 2 months of treatment with repeat $\mathrm{Hb}$ estimation to observe any increase in $\mathrm{Hb}$. Women were also advised to report immediately if there were any adverse effects, like nausea, vomiting, metallic taste, constipation and diarrhea.

The results were analyzed using the students ' $t$ ' test and chi-square test, a $\mathrm{p}$ value of $<0.05$ was statistically significant, a $\mathrm{p}$ value of $<0.01$ was considered highly significant and a $\mathrm{p}$ value of $<0.001$ was very highly significant.

\section{RESULTS}

74 women were divided into two group of 37 in each. Out of 37 women in FS group 7 women and 4 women in FD group were dropped out from the study. So, the total number of women in FS group and in FD group were 30 and 33 respectively. The study did not show any statistical difference among the two groups with respect to age and parity. The occupation between the two groups were statistically comparable. With respect to gestational age there was no significant statistical difference.

Mean $\mathrm{Hb}$ was compared in both the groups at recruitment of the study and both groups were statistically comparable. After 1 month of treatment in both the groups the mean $\mathrm{Hb}$ was compared and no significant statistical difference was found. Similarly, mean $\mathrm{Hb}$ after 2 months of treatment was compared in both the groups, both groups were again statistically comparable (Table $1)$.

Table 1: Comparison of $\mathrm{Hb}(\mathrm{g} / \mathrm{dl})$ between two groups.

\begin{tabular}{llll}
$\mathrm{Hb}$ & $\begin{array}{l}\text { Group FS } \\
(\mathbf{n}=30)\end{array}$ & $\begin{array}{l}\text { Group FD } \\
(\mathbf{n}=33)\end{array}$ & P value* \\
\hline $\mathrm{Hb} 0$ & $9.18 \pm 1.17$ & $8.79 \pm 1.39$ & $0.23 \mathrm{NS}$ \\
\hline $\mathrm{Hb} 1$ & $10.19 \pm 1.15$ & $10.08 \pm 1.41$ & $0.74 \mathrm{NS}$ \\
\hline $\mathrm{Hb} 2$ & $10.77 \pm 1.13$ & $10.91 \pm 1.38$ & $0.65 \mathrm{NS}$ \\
\hline
\end{tabular}

$\mathrm{Hb} 0: \mathrm{Hb}$ at recruitment of study. $\mathrm{Hb} 1: \mathrm{Hb}$ after 1 month of treatment. $\mathrm{Hb} 2: \mathrm{Hb}$ after 2 months of treatment.

The mean $\mathrm{Hb}$ rise was compared between FS and FD groups after 1 month of treatment showed statistically very high significant difference. Similarly, $\mathrm{Hb}$ rise after 2 months of treatment also showed high significant difference. The mean $\mathrm{Hb}$ rise between 1 month of treatment and 2 months of treatment also showed statistically highly significant difference between FS and FD groups (Figure 1).

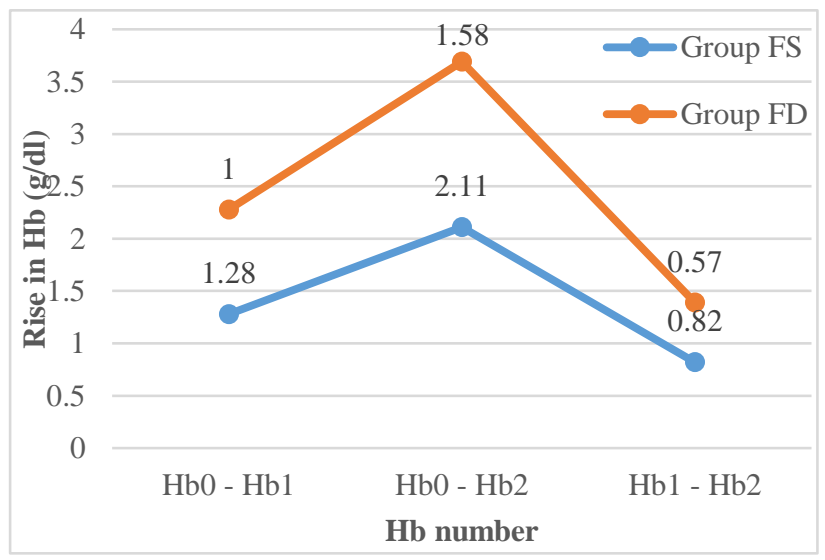

Figure 1: Comparison of mean $\mathrm{Hb}$ rise in both groups.

More number of pregnant women in ferrous sulfate group $(60 \%)$ had nausea compared to sodium feredetate group $(3 \%)$.

The $\mathrm{p}$ value was very highly significant. More number of pregnant women in ferrous sulfate group noticed metallic taste than in FD group. So, the $\mathrm{p}$ value was highly significant (Table 2). 
Table 2: Metallic taste between two groups.

\begin{tabular}{|c|c|c|c|}
\hline & Absent & Present & P value* \\
\hline Group FD $(n=33)$ & $33(100 \%)$ & $0(0 \%)$ & $P=0.009$ \\
\hline Group & 24 & & $\begin{array}{l}\text { Highly } \\
\text { significant }\end{array}$ \\
\hline
\end{tabular}

Both FS and FD groups when compared for vomiting, no statistically significant difference was found (Table 3 ).

Table 3: Vomiting between two groups.

\begin{tabular}{|llll|}
\hline Group FD(n=33) & Absent & Present & P value* \\
\cline { 1 - 2 } Group FS(n=30) & $29(96.7 \%)$ & $1(3.3 \%)$ & NS \\
\hline
\end{tabular}

Pregnant women in FS group had constipation and diarrhea than in FD group. The $\mathrm{p}$ value was significant when both groups were compared (Table 4, Table 5).

Table 4: Constipation comparison between two groups.

\begin{tabular}{|llll|}
\hline & A bsent & Present & P value* \\
\hline Group FD(n=33) & $28(84.9 \%)$ & $5(15.1 \%)$ & $\mathrm{P}=0.026$ \\
\hline Group FS(n=30) & $18(60 \%)$ & $12(40 \%)$ & Significant \\
\hline
\end{tabular}

Table 5: Diarrhoea between two groups.

\begin{tabular}{|llll|}
\hline & A bsent & Present & P value* \\
\cline { 1 - 2 } Group FD (n=33) & $33(100 \%)$ & $0(0 \%)$ & P = 0.046 \\
\cline { 1 - 3 } Group FS (n=30) & $26(86.7 \%)$ & $4(13.3 \%)$ & Significant \\
\hline
\end{tabular}

\section{DISCUSSION}

Anemia is commonest medical disorder of pregnancy. Anemia is a major contribution to maternal morbidity and mortality with adverse perinatal outcome. According to WHO 35 to $75 \%$ of pregnant anemic women are in the developing countries. The total number of anemic women residing in Indian subcontinent among which $88 \%$ are pregnant and constitute world's half of the world's total women. ${ }^{5}$

In our study, we aimed at comparison of Sodium Feredetate and Ferrous Sulfate in improving $\mathrm{Hb}$ profile after one and two months of treatment with respective drugs and their side effects. In the present study, we found that in Ferrous Sulfate group, mean $\mathrm{Hb}$ at recruitment of study was $9.18 \pm 1.17 \mathrm{~g} / \mathrm{dl}$.

After one month of treatment mean $\mathrm{Hb}$ increased to $10.19 \pm 1.15 \mathrm{~g} / \mathrm{dl}$ and after 2 months of treatment $\mathrm{Hb}$ increased to $10.77 \pm 1.13 \mathrm{~g} / \mathrm{dl}$. A similar study was done in Safdarjang hospital with 21 patients with Ferrous Sulfate mean $\mathrm{Hb}$ at recruitment at study was $8.21 \pm 0.70 \mathrm{~g} / \mathrm{dl}$. After 1 month and 2 months of treatment $\mathrm{Hb}$ increased to $9.24 \pm 0.64 \mathrm{~g} / \mathrm{dl} 10.08 \pm 0.74 \mathrm{~g} / \mathrm{dl}$ respectively. ${ }^{6}$
The mean rise of $\mathrm{Hb}$ after 1 month and 2 months of treatment with ferrous sulfate tablets was $1.00 \mathrm{~g} / \mathrm{dl}$ and $1.58 \mathrm{~g} / \mathrm{dl}$ respectively while in Safdarjang Hospital study $[\mathrm{N}=21]$, the mean $\mathrm{Hb}$ rise after 1 month and 2 months of treatment was $1.03 \mathrm{~g} / \mathrm{dl}$ and $1.9 \mathrm{~g} / \mathrm{dl}$ respectively.

In our study with sodium feredetate group $\mathrm{Hb}$ at recruitment of study was $8.79 \pm 1.39 \mathrm{~g} / \mathrm{dl}$. After 1 month and 2 months of treatment $\mathrm{Hb}$ was $10.08 \pm 1.41 \mathrm{~g} / \mathrm{dl}$ and $10.91 \pm 1.38 \mathrm{~g} / \mathrm{dl}$ respectively. While in Safdarjang Hospital study, $\mathrm{Hb}$ at beginning of study was $8.58 \pm 1.09$ $\mathrm{g} / \mathrm{dl}$ after 1 month and 2 months of treatment $\mathrm{Hb}$ became $10.32 \pm 1.07 \mathrm{~g} / \mathrm{dl} 11.44 \pm 1.05 \mathrm{~g} / \mathrm{dl}$ respectively.

In present study mean rise in $\mathrm{Hb}$ with $\mathrm{FD}$ after 1 month and 2 months of treatment was $1.28 \mathrm{~g} / \mathrm{dl}$ and $2.11 \mathrm{~g} / \mathrm{dl}$ respectively. In Safdarjang Hospital study [n=45] mean rise in $\mathrm{Hb}$ with $\mathrm{FD}$ after 1 month of treatment was 1.75 $\mathrm{g} / \mathrm{dl}$ and $2.95 \mathrm{~g} / \mathrm{dl}$ after 2 months of treatment. While in Sarkate et al study [ $n=12$ ] sodium feredetate $(33 \mathrm{mg})$ was given twice a day, they found that mean $\mathrm{Hb}$ rise after 1 month of treatment was $1.1 \mathrm{~g} / \mathrm{dl}$ and 2 months of treatment was $1.48 \mathrm{~g} / \mathrm{dl}$ respectively and with sodium feredetate $(66 \mathrm{mg} \mathrm{Bd})$ mean $\mathrm{Hb}$ rise after 1 month of treatment was $1.39 \mathrm{~g} / \mathrm{dl}$ and 2 months of treatment and $1.31 \mathrm{~g} / \mathrm{dl}$ respectively. ${ }^{7,8}$

In the present study, we found that $\mathrm{Hb}$ rise after 1 month and 2 months of treatment in sodium feredetate was found very highly significant $(\mathrm{p}<0.001)$ as compared to ferrous sulfate group. So, sodium feredetate is a more efficient drug as compared to ferrous sulfate. In Safdarjang Hospital study also they found that after 1 month and 2 months of treatment with FD mean rise of $\mathrm{Hb}$ was $1.75 \mathrm{~g} / \mathrm{dl}$ and $2.95 \mathrm{~g} / \mathrm{dl}$ respectively and in ferrous sulfate group it was $1.1 \mathrm{~g} / \mathrm{dl}$ and $1.9 \mathrm{~g} / \mathrm{dl}$ again their study concluded that sodium feredetate was superior drug on ferrous sulfate in improving $\mathrm{Hb}$ profile $(\mathrm{p}<0.001)$ statistically significant. ${ }^{7}$ In the present study the adverse effects clinically and statistically were found more in ferrous sulfate group as compared to sodium feredetate group.

Previous studies with $\mathrm{Hb}$ at beginning of the study mean $\mathrm{Hb}$ rise after 1 month and 2 months of treatment with ferrous sulfate were respectively. Safdarjang Hospital Study $\mathrm{n}=21, \mathrm{Hb}_{\mathrm{o}} \rightarrow 8.21 \pm 0.70, \mathrm{Hb}_{1} \rightarrow 9.24 \pm 0.64, \mathrm{Hb}_{2} \rightarrow$ $10.08 \pm 0.74 .^{6}$ Present Study $[\mathrm{n}=30], \mathrm{Hb}_{\mathrm{o}} \rightarrow 9.18 \pm 1.17$, $\mathrm{Hb}_{1} \rightarrow 10.19 \pm 1.15, \mathrm{Hb}_{2} \rightarrow 10.77 \pm 1.13$. So, mean $\mathrm{Hb}$ rise in ferrous sulfate group after 1 month and 2 months of treatment were respectively. Safdarjang Hospital Study, $\mathrm{n}=21,1.0,1.9$. Present Study, $\mathrm{n}=30,1.0,1.58$. Hb at beginning of study mean $\mathrm{Hb}$ rise after 1 month and 2 months of treatment with sodium feredetate was as follows; Safdarjang Hospital Study, [n=45], $\mathrm{Hb}_{0} \rightarrow 8.58 \pm 1.09, \mathrm{Hb}_{1} \rightarrow 10.32 \pm 1.107, \mathrm{Hb}_{2} \rightarrow 11.44 \pm 1.05$. Present Study, [n=33], $\quad \mathrm{Hb}_{0} \rightarrow 8.79 \pm 1.39, \quad \mathrm{Hb}_{1} \rightarrow$ $10.08 \pm 1.41, \mathrm{Hb}_{2} \rightarrow 10.91 \pm 1.38$. So, mean rise in $\mathrm{Hb} \mathrm{g} / \mathrm{dl}$, Safdarjang hospital study, $\mathrm{n}=45$ with $33 \mathrm{mg}$ of sodium feredetate OD $\rightarrow 1.75 \rightarrow 2.95$ In Sarkate et al study, $n=12$ 
with $33 \mathrm{mg}$ of sodium feredetate $\rightarrow 1.1 \rightarrow 1.48$, with $66 \mathrm{mg}$ of $\mathrm{Bd}$ sodium feredetate $\rightarrow 1.39,1.31$ respectively. ${ }^{8}$ Present study, [n=33], 1.28, 2.11 respectively So, we found that in our study mean $\mathrm{Hb}$ rise after 1 month and 2 months of treatment in sodium feredetate group was found very highly significant $[\mathrm{p}<0.001]$ as compared to ferrous sulfate group. In the above mentioned other two studies, also they found that SF was superior drug as compared to ferrous sulphate in improving $\mathrm{Hb}$ profile [p<0.001-statistically significant.$^{7,8}$ Comparing side effects in both the groups with FS and FD group and with other studies. So, we found that the sodium feredetate is having lower incidence of side effects as compared to ferrous sulfate. ${ }^{7}$ In Wang et al study with sodium feredetate there was increase in both serum ferritin and Hb concentration. ${ }^{9}$ Sodium feredetate [Na Fe EDTA] in iron deficiency anemia led to a significant and rapid rise in hemoglobin levels than that with ferrous sulfate in our study. Furthermore, sodium feredetate is also associated with minimal or almost nil side effects due to better compliance as compared with ferrous sulfate. In present study sodium feredetate is having good bioavailability, well tolerated and patients responded well to sodium feredetate treatment.

The only drawback we have experienced with sodium feredetate for treatment of anemia compared to ferrous sulfate is its higher cost factor which probably cannot be afforded by all the patients in our setup. Hence to conclude, sodium feredetate as compared to ferrous sulfate is

- More efficient drug to treat iron deficiency anemia in pregnant women.

- Better tolerated and have comparably low incidence of side effects.

\section{CONCLUSION}

Thus, sodium feredetate can be used as an effective and promising iron supplement in pregnant women with iron deficiency anemia in comparison to ferrous sulfate.
Funding: No funding sources Conflict of interest: None declared

Ethical approval: The study was approved by the Institutional Ethics Committee

\section{REFERENCES}

1. World Health Organization. WHO Global Database. Geneva: WHO; 1999.

2. Gillooly M. The effect of organic acids, phytates and polyphenols on absorption of iron from vegetables. Br J Nutr. 1983;49:331-42.

3. Hallberg L, Brune M. and Rossander. Iron absorption in man: ascorbic acid and dose dependent inhabitation by phytate. Am J Clin Nutr. 1989;49: $140-4$.

4. Schwartz WJ, Thurnau GR. Iron deficiency anemia in pregnancy. Clin Obstet Gynecol. 1995;38:443-54.

5. Stoltzfus RJ, Dreyfuss ML. Guidelines for the use of iron supplements to prevent and treat iron deficiency anemia. Geneva: INACG/ UNICEF/ WHO; 1998.

6. The efficacy of sodium feredetate and ferrous sulfate in the treatment of iron deficiency anemia in Indian Patients. Obs and Gynae Today. 2006;11(1).

7. Sarkate P, Patil A, Parulekar S. A Randomised Double Blind study comparing sodium feredetate with ferrous sulfate in Anemia in Pregnancy. J Indian Med Assoc. 2007;105:278-81.

8. Wang. Effect of $\mathrm{Na} \mathrm{Fe}$ EDTA $\mathrm{On} \mathrm{Hb}$ and serum ferritin in $\mathrm{Fe}$ deficient populations; a systematic review and meta-analysis of randomized and quasirandomized controlled trials. $\mathrm{Br} \mathrm{J}$ Nutrition. 2008;100(6):1167-78.

Cite this article as: Revankar VM, Garg A, Revankar MG. Efficacy of sodium feredetate versus ferrous sulfate in iron deficiency anemia in preganant women. Int J Reprod Contracept Obstet Gynecol 2017;6:1978-81. 